\title{
3 Research Suare \\ The Effect of Aflibercept and Arsenic Trioxide on the Proliferation, Migration and Apoptosis of Oral Squamous Cell Carcinoma in Vitro
}

\section{Samira Derakhshan}

Tehran University of Medical Sciences

Pouyan Aminishakib

Tehran University of Medical Sciences

Fatemeh Pirzadeh

Tehran University of Medical Sciences

Sedigheh Rahrotaban

Tehran University of Medical Sciences

Parvaneh Farzaneh

Tehran University of Medical Sciences

Sahar Tavakoli Shiraji

Tehran University of Medical Sciences

Meysam Ganjibakhsh

royan insitute

masoumeh asadi ( $\triangle$ masome.asadi@gmail.com )

IBRC https://orcid.org/0000-0002-4824-3058

Original Article

Keywords: Oral Squamous Cell Carcinoma, OCC, Aflibercept, Arsenic Trioxide

Posted Date: February 8th, 2021

DOI: https://doi.org/10.21203/rs.3.rs-179169/v1

License: (c) (1) This work is licensed under a Creative Commons Attribution 4.0 International License.

Read Full License 


\section{Abstract}

Aflibercept and arsenic trioxide drugs apply a cytotoxic effect on some human cancer cell lines. However, no more study has followed the effects of both drugs, especially arsenic trioxide, on oral squamous cell carcinoma (OCC). We used three OCC lines as a model to show the effect of these drugs on the genetically complex disease and investigate its targeted therapy.

In this study, three human OCC cell lines were used from different patients. We treated cell lines with both medications to detect the effect and relevant molecular basis. First, methyl thiazolyl tetrazolium (MTT) assay was performed to detect the cytotoxicity effect and cell growth. Second, western blot and flow cytometry were performed to evaluate the anti-angiogenic effect on OCC lines. Next apoptosis was analyzed by flow cytometry. Finally, clonogenesis capacity and cell migration were assessed by colony formation assay and wound healing, respectively.

Aflibercept had no cytotoxic effect on the three OCC cell lines but decreased cell growth rate. Arsenic trioxide had a significant cytotoxic effect on three cell lines. Our results demonstrated that both drugs significantly decreased endoglin and VEGF expression. In addition, Migration and colony formation assays confirmed that these drugs have significant anti-proliferative and anti-migration effect on oral carcinoma cells.

These results revealed that both medications might be a potential drug for the management of oral cancer patients.

\section{Introduction}

Oral squamous cell carcinoma (OCC) accounts for over $90 \%$ of the oral malignancies (Tandon et al., 2017, Markopoulos, 2012). According to a Ferlay and et al study in 2015, 300 000 new cases of oral malignancies were diagnosed worldwide and the mortality rate was about 145,000 (Ferlay et al., 2015). Despite all the developments in treatment of OCC, the survival rate has remained low and satisfying improvement in the outcome of the patients has not been achieved (Ausoni et al., 2016). Surgery, chemotherapy, and radiotherapy have been the first-line treatment for cancer for long (Zheng et al., 2018). Regardless of therapeutic advances, the treatment outcome remains disappointing, especially for cases diagnosed in advanced stages (Pulte and Brenner, 2010). Moreover, the available treatment modalities for the primary and metastatic OCC are often limited, and are mainly comprised of palliative treatment. Thus, researchers are attempting to find new treatment strategies for OCC (Gong et al., 2017). Another approach in cancer therapy is to use anti-angiogenic medications such as bevacizumab, aflibercept, sunitinib, pazopanib, ranibizumab, and arsenic trioxide (Teleanu et al., 2020). Aflibercept has been effective on several tumors in vitro and ex vivo. It exerts its anti-angiogenic effects by regression of tumor vessels and vascular remodeling, and inhibition of neovascularization (Auvray et al., 2019, Ganjibakhsh et al., 2018).

Arsenic trioxide is a traditional Chinese medicine that has been used for many years. This medication is currently used clinically for treatment of acute promyelocytic leukemia by targeting PML/RARA; however, 
it has a wider range of activity (Nasr, 2010). A high concentration of arsenic trioxide can induce apoptosis in leukemic cells (Baysan et al., 2007). In this study we evaluated the response of three OCC cell lines, isolated from different patients, when treated with aflibercept and arsenic trioxide as anti-angiogenic and anti-proliferative drugs.

\section{Materials And Methods}

\section{Cell lines and quality control}

Three human OCC cell lines (OCC-11, OCC-18, and OCC-20) were used in the study (supplementary, table 1). The establishment and authenticated of all three cell lines were performed before freezing and banking in human and animal Iranian cell bank, Iranian biological Resource Center, Tehran, Iran. To detect bacterial, yeast, fungal contaminations, the supernatant of cells was cultured in tryptone soy broth and thioglycollate broth media for 14 days. In addition, mycoplasma contamination was evaluated using DNA staining with Hoechst, direct solid agar microbiological culture and mycoplasma PCR. Finally, for authentication of the cells STR assay was done (Ganjibakhsh et al., 2017). The ethical committee of Tehran University approved this study (IR.TUMS.DENTISTRY.REC.1397.146) and supported by Tehran University of Medical Sciences (Grant \#97-03-69-39794). This study was approved by the ethics committee of Tehran University of Medical Sciences (IR.TUMS.DENTISTRY.REC.1397.146) and was financially supported by a grant from this university (Grant \#97-03-69-39794).

\section{Methyl thiazolyl tetrazolium (MTT) assay:}

The MTT assay was performed to assess the cytotoxic effects of aflibercept and arsenic trioxide on cell proliferation (Sheikholeslami et al., 2019). The cell lines were seeded at a concentration of $5 \times 10^{4}$ cells/well for cytotoxicity testing, and $2 \times 10^{3}$ cells/well for the proliferation assay in a 96-well plate, and incubated at $37^{\circ} \mathrm{C}$ overnight. The supernatant was replaced by a serum-free medium. The cells were then treated with the two drugs in the following groups:

Control group: OCC cells + culture medium

Aflibercept group: OCC cells + culture medium $+20,100,500$ or $2500 \mu \mathrm{g} / \mathrm{mL}$ aflibercept

Arsenic trioxide group: OCC cells + culture medium $+5,10,15,20$, or $30 \mu \mathrm{M} / \mathrm{mL}$ arsenic trioxide

The results were read after 24, 48, and $72 \mathrm{~h}$. The MTT solution (Sigma, St. Louis, USA) was added to each well at a final concentration of $250 \mu \mathrm{g} / \mathrm{mL}$. The plates were incubated at $37^{\circ} \mathrm{C}$ for $3 \mathrm{~h}$ and then, $150 \mu \mathrm{L}$ of the MTT solvent was added to each well. The optical density of each well was measured by reading the absorbance of the wells at $570 \mathrm{~nm}$ wavelength (Van Meerloo et al. 2011).

\section{Effect of aflibercept and arsenic trioxide on expression of VEGF protein:}


The western blot assay was performed to evaluate the effect of aflibercept and arsenic trioxide on the expression of VEGF by the three OCC cell lines. The cells were seeded into 6-well plates and incubated at $37^{\circ} \mathrm{C}$ in complete culture medium overnight. Next, the cells were treated with aflibercept and arsenic trioxide at a final concentration of $100 \mu \mathrm{g} / \mathrm{mL}$ and $10 \mu \mathrm{M} / \mathrm{mL}$, respectively, for $48 \mathrm{~h}$. Untreated cells served as the control group.

After $48 \mathrm{~h}$, the cells were collected and centrifuged, and the expression of VEGF was assessed using VEGF Human Western Blot Kit (Abcam, Cambridge, MA, USA, Number code: ab46154) using 1:1000 concentration for primary antibody and 1:4000 for secondary antibody (Abcam, Cambridge, MA, USA, DB9572), according to the manufacturer's instructions.

\section{Effect of aflibercept and arsenic trioxide on endoglin expression:}

The flow cytometric assay was performed to assess the effect of aflibercept and arsenic trioxide on endoglin expression by the three OCC cell lines. The cells were cultured in complete culture medium at $37^{\circ} \mathrm{C}$ overnight, and were then treated with aflibercept $(100 \mu \mathrm{g} / \mathrm{mL})$ and arsenic trioxide $(10 \mu \mathrm{M} / \mathrm{mL})$. Untreated cells served as the control group. After $48 \mathrm{~h}, 2 \mu \mathrm{g} / \mathrm{mL}$ of endoglin conjugated primary antibody (Abcam, Cambridge, MA, USA, ab11415) was added, followed by incubation for a minimum of $30 \mathrm{~min}$ at $4^{\circ} \mathrm{C}$. The samples were analyzed with FlowJo software version 10.

\section{Apoptosis assay:}

The three cell lines were treated with the two drugs to assess the apoptotic effect of the drugs. The assay was performed using the FITC Annexin V, Apoptosis Detection Kit I (BD Biosciences, San Jose, USA). The cells $\left(100 \times 10^{3}\right.$ cells/well) were seeded in 6-well plates and treated with $100 \mu \mathrm{g} / \mathrm{mL}$ aflibercept and 10 $\mu \mathrm{M} / \mathrm{mL}$ arsenic trioxide, and incubated along with the non-treated control cells for $48 \mathrm{~h}$. Annexin $\mathrm{V}$ and propidium iodide were added to the suspended cell tubes and incubated in the dark for $30 \mathrm{~min}$ at room temperature. Finally, the cells underwent flow cytometric analysis.

\section{Colony formation assay:}

The colony formation assay was performed according to the protocol described by Franken (Franken et al., 2006). Single cells were seeded in a 6-well plate $\left(1 \times 10^{2}\right.$ cells $)$ and allowed to attach overnight and were then exposed to a final concentration of $100 \mu \mathrm{g} / \mathrm{mL}$ aflibercept and $10 \mu \mathrm{M} / \mathrm{mL}$ arsenic trioxide for $48 \mathrm{~h}$. Next, the medium was refreshed, and the cells were incubated at $37^{\circ} \mathrm{C}$. After 14 days, the cells were fixed and stained with $10 \%$ methylene blue in $70 \%$ ethanol. The number of colonies was counted and the fraction of survived cells was calculated as the ratio of the number of colonies in the treated sample to the number of colonies in the untreated sample. Five replicate wells were seeded for each drug.

\section{Scratch test:}

The scratch test was performed to assess the effect of aflibercept and arsenic trioxide on cell migration (Ganjibakhsh et al., 2018). The cell monolayer was scraped in a straight line to create a scratch with a 
p100 pipette tip. The cells were washed to remove the debris and smoothen the edge of the scratch and were then added with $5 \mathrm{~mL}$ of complete culture medium with $100 \mu \mathrm{g} / \mathrm{mL}$ aflibercept and $10 \mu \mathrm{M} / \mathrm{mL}$ arsenic trioxide. Photographs were taken at 0,24 , and $48 \mathrm{~h}$ after incubation under an inverted microscope. The photographs were quantified using Image $\mathrm{J}$ software.

\section{Statistical analysis}

Data from different experimentations expressed as mean \pm standard deviation, and analyzed by one-way or two-way ANOVA using GraphPad Prism 7.0 software. P-value $<0.05$ was considered statistically significant. For reproducibility, the MTT and colony formation assays were performed in five replicates, by three independent experiments. Other experiments were conducted in three independent biological replicates. The results of western blot test and the number of formed colonies were quantified by Image $\mathrm{J}$ and analyzed by GraphPad software.

\section{Results}

The result of contamination assays showed there is no contamination and STR assay detected no misidentified (supplementary, figure S1 and S2).

\section{MTT assay:}

To assess the possible cytotoxic effects of the two medications on cells, all three cell lines were exposed to 5-30 $\mu \mathrm{M}$ arsenic trioxide and $20-2500 \mu \mathrm{g}$ aflibercept for 24,48 , and $72 \mathrm{~h}$. The results revealed that aflibercept had no cytotoxic effect on the three OCC cell lines. In order to assess the effect of aflibercept on proliferation of OCC cells, we treated the cells with 20-2500 $\mu \mathrm{g}$ aflibercept, and the result was analyzed. A reduction in cell proliferation was observed in the aflibercept-treated group compered to nontreated cells. Aflibercept significantly decreased the proliferation of OCC cells; between OCC11 and OCC18 [ $(24 \mathrm{~h}, \mathrm{p}<0.01$ at $100 \mu \mathrm{g}$, and $\mathrm{p}<0.0001$ at 500 and $2500 \mu \mathrm{g})(48 \mathrm{~h}$ and $72 \mathrm{~h}, \mathrm{p}<0.0001$ at 20, 100, 500 , and $2500 \mu \mathrm{g})$ ], between OCC-11 and OCC-20 [(24 h, p < 0.0001 at 500 and $2500 \mu \mathrm{g})(48 \mathrm{~h} \mathrm{p}<0.0001$ at $20,500,2500 \mu \mathrm{g})(48 \mathrm{~h} \mathrm{p}<0.001$ at $100 \mu \mathrm{g}$, and $72 \mathrm{~h}$ at $500 \mu \mathrm{g})(72 \mathrm{~h}, \mathrm{p}<0.01 \mathrm{at} 2500 \mu \mathrm{g})]$ and between OCC-18 and OCC-20 [(24 h, p $<0.0001$ at 500 and $2500 \mu \mathrm{g}, \mathrm{p}<0.01$ at $100 \mu \mathrm{g})(48 \mathrm{~h}, \mathrm{p}<0.0001$ at 20,500, and $2500 \mu \mathrm{g})(72 \mathrm{~h}, \mathrm{p}<0.0001$ at 20 , and $100 \mu \mathrm{g})]$. The results of the correlational analysis are shown in Figure 1A-C. Arsenic trioxide showed significant cytotoxic effect $(P<0.05)$ (Figure 1D-F).

Arsenic trioxide induced significant cell death in OCC cells; between OCC11 and OCC-18 [ $(24 \mathrm{~h}$ and $48 \mathrm{~h}, \mathrm{p}$ $<0.0001$ at $5 \mu \mathrm{M})(72 \mathrm{~h}, \mathrm{p}<0.0001$ at $15 \mu \mathrm{M})(24 \mathrm{~h}, \mathrm{p}<0.05$ at $20 \mu \mathrm{M}),(48 \mathrm{~h}, \mathrm{p}<0.01$ at $20 \mu \mathrm{M}),,(72 \mathrm{~h}, \mathrm{p}$ $<0.001$ at $20 \mu \mathrm{M}),(48 \mathrm{~h}, \mathrm{p}<0.0001$ at $10 \mu \mathrm{M})$ ], between OCC-11 and OCC-20 [(72 h, p < 0.0001 at $15 \mu \mathrm{M})$ ], and between OCC-18 and OCC-20 [(24h, p $<0.001$ at 5 and $15 \mu \mathrm{M}, \mathrm{p}<0.05$ at $30 \mu \mathrm{M})(48 \mathrm{~h}, \mathrm{p}<0.0001$ at $5 \mu \mathrm{M})(48 \mathrm{~h}, \mathrm{p}<0.01$ at 10 , and $20 \mu \mathrm{M}),(72 \mathrm{~h}, \mathrm{p}<0.05$ at $20 \mu \mathrm{M})]$.

Selection of $10 \mu \mathrm{M}$ arsenic trioxide was in accord with a previous study (Park et al., 2003) and the selected concentration of aflibercept $(100 \mu \mathrm{g})$ was based on the results of our previous study at $48 \mathrm{~h}$ (Ganjibakhsh et al., 2018). 


\section{Effect of aflibercept and arsenic trioxide on VEGF expression:}

The western blot assay was performed to assess the expression of VEGF at the protein level in treated and untreated OCC cell lines. The results showed that both drugs significantly decreased the expression of VEGF in all OCC cell lines in comparison with the control group (Figure 2A-F). As shown in Figure 2, the greatest reduction in VEGF expression was observed in OCC-20 cell line treated by arsenic trioxide in comparison with the control group $(p<0.0001)$ (Figure $2 F)$.

\section{Effect of aflibercept and arsenic trioxide on endoglin expression:}

In order to study the expression of endoglin, three cell lines were treated with aflibercept $(100 \mu \mathrm{g})$, and arsenic trioxide $(10 \mu \mathrm{M})$, and underwent flow cytometry assay after $48 \mathrm{~h}$. Aflibercept caused the greatest reduction in endoglin expression in all three cell lines compared with cells treated with arsenic trioxide and untreated cells. It is apparent from figure 3 that OCC-11 was more resistant to other groups when treated by aflibercept and arsenic trioxide (Figure 3A-D).

\section{Effect of aflibercept and arsenic trioxide on cell apoptosis:}

In order to assess whether aflibercept and arsenic trioxide induce cell death by apoptosis, OCC-11, OCC18 , and OCC-20 cell lines were treated with aflibercept $(100 \mu \mathrm{g}, 48 \mathrm{~h})$ and arsenic trioxide $(10 \mu \mathrm{M}, 48 \mathrm{~h})$ and then underwent flow cytometry. Analysis of the results indicated that aflibercept had no significant apoptotic effect on the three OCC cell lines. However, a significant increase was noted in the percentage of apoptotic cells in OCC-20 cell line treated by arsenic trioxide. Our results showed that arsenic trioxide induced apoptosis in OCC-20 cell line significantlymore than OCC-18 and had no effect on OCC-11 cell line (Figure 4A-D).

\section{Effect of aflibercept and arsenic trioxide on cell proliferation and colony formation:}

The colony formation assay was performed to quantify the proliferation of treated cells. No colony formed after 14 days when the cells were treated with arsenic trioxide (Figure 5A, C, E). Also, aflibercep significantly decreased the number of colonies in three primary cancer cell lines compared with the control group $(p<0.001)$.

\section{Effect of aflibercept and arsenic trioxide on cell migration:}

The scratch test was performed in absence and presence of the drugs to assess the motility and migration of cells after exposure to aflibercept and arsenic trioxide. The results showed decreased cell migration following treatment with arsenic trioxide [OCC-11 $(p<0.001)$ and OCC-20, OCC-18 $(p<0.0001)$ ] and aflibercept [OCC-11 and OCC-20 ( $p<0.05)$ ] at $24 \mathrm{~h}$. After $48 \mathrm{~h}$, only arsenic trioxide-treated OCC-11 cells showed a significant decrease $(p<0.01)$ and migration of cells decreased significantly in OCC-18 and OCC-20 ( $<<0.0001)$. Also, the migration rate of aflibercept-treated cells decreased in OCC-18 and OCC-20 lines $(p<0.05)$ compared with the control group (Figure 6A-F). Overall, our results indicated that both drugs reduced the migration and mobility of cancer cells. 


\section{Discussion}

A number of molecular factors are involved in tumorigenesis of OCC (Zheng et al., 2018). In the recent years, researchers have focused on genetic alterations in OCC to detect novel molecular targets which could be both effective and predictive for treatment response. Currently, some protocols have been established for sample collection, storage, detailed techniques, and proper analytical approaches in targeted therapy. Although Bonner et al. reported that cetuximab (Erbitux) is a medication for targeted therapy in OCC, this medication is used in combination with chemotherapy (Bonner et al., 2010, Riley et al., 2016). It should be noted that in cancer, sometimes the formed vessels have pathological (abnormal) structures that resist the receipt of medications, including chemotherapeutic agents. Aflibercept can return the normal structure of such vessels to make them susceptible to various medications (RodríguezRemírez et al., 2020). Aflibercept may be effective in combination with the conventional surgical procedures for treatment of oral cancer (Ganjibakhsh et al., 2018). In addition, arsenic trioxide has antiangiogenic effects, and can decrease the density of small vessels (Zheng et al., 2018). It can also prevent cell growth and differentiation because of its effects on various aspects of cellular activity (Miller et al., 2002). It has been observed that arsenic trioxide induces apoptosis by rebooting the WNT signaling pathway in cancer cells, and prevents angiogenesis by inhibiting the vascular endothelial growth factor (VEGF) (Zheng et al., 2018). Recently, investigators examined the effects of arsenic trioxide on hematological malignancies and showed its optimal efficacy (Kuivenhoven and Mason, 2019).

We investigated different effects of aflibercept and arsenic trioxide on three primary OCC cell lines. Several reports have shown the anti-angiogenic effects of arsenic trioxide and aflibercept on different cancer types. Our results indicated that the tested drugs had different effects on each cell line isolated from different patients, which was in agreement with the personalized medicine concept. In reviewing the literature, impressive results have been reported for cancer treatment using personalized medicine (Druker et al., 2006, Fisher et al., 2013, Van Cutsem et al., 2011). However, only a limited number of targeted therapies have been implemented on OCC patients (Network, 2015). Our results indicated that treatment of OCC-18 and OCC-20 cell lines with arsenic trioxide significantly increased the number of apoptotic cells, unlike the aflibercept-treated cells. Interestingly, OCC-11 cells had less apoptotic response in comparison with the other two groups, suggesting that OCC cells isolated from different patients may show different responses to treatment with arsenic trioxide and aflibercept. In agreement with our results, Kumar et al. showed that arsenic trioxide significantly decreased the cell survival rate of OCC (Kumar et al., 2008).

As reported before, endoglin expressed in high level and play a significant role in the advanced level of such malignancies (Mărgăritescu et al., 2008); we studied the anti-angiogenic activity of aflibercept and arsenic trioxide against three $\mathrm{OCC}$ cell lines, aiming to identify the most effective targeted drug in different patients. The flow cytometric analysis showed that endoglin expression significantly decreased in all treated groups. Surprisingly, OCC-11 was resistant to both aflibercept and arsenic trioxide. VEGF expression patterns confirmed the endoglin expression results, suggesting that aflibercept and arsenic trioxide induced anti-angiogenic effects on each cell line through a different mechanism. This finding 
broadly supports other studies in this field. Giuliani et al. showed that aflibercept, with greater antiangiogenic effects, might be effective in treatment of OCC in combination with the conventional surgical procedures (Giuliani and Bonetti, 2016).

Monitoring the patients taking aflibercept is highly recommended because of the common side effects of aflibercept including medication-related osteonecrosis of the jaw, hypertension, and some clinical signs and symptoms of toxicity (Giuliani and Bonetti, 2016, Mawardi et al., 2016). On the other hand, there are limited studies that investigated the efficacy of aflibercept in comparison with other anti-angiogenictargeted drugs in OCC patients.

The mechanism of action of arsenic trioxide as an anti-cancer drug involves apoptosis, induction of differentiation, inhibiting the mitochondrial permeability, and inducing the generation of reactive oxygen species (Cai et al., 2003, Chen et al., 1998). However, the anti-angiogenic effects of arsenic trioxide on cancers especially OCC have remained unclear.

Wang et al. claimed that arsenic trioxide in a combined treatment regimen can be a novel and effective therapeutic strategy for OCC (Cai et al., 2003). Nakaoka et al. suggested a combination of arsenic trioxide and cisplatin as anti-apoptotic agents for OCC for the first time (Nakaoka et al., 2014). Additionally, it should be noted that arsenic trioxide is affordable and available.

It has been reported that anti-cancer drugs suppress the migration and colony formation of several cancer types (Liu et al., 2016). For a clear understanding, we investigated the suppressive effects of aflibercept and arsenic trioxide on three OCC cell lines using the colony formation and migration assays. We found that these drugs inhibited cell migration and colony formation in OCC. In addition, we observed that cell migration significantly decreased in OCC-18 and OCC-20 in comparison with OCC-11. It is interesting to note that in all three cell lines, no colony formation observed when the cells were treated with arsenic trioxide for 14 days.

Tandberg et al, in a recent study showed characterization of the mutational landscape of OCC which was demonstrated by single-site biopsy and could have implications for personalized medicine (Zandberg et al., 2019). In future years, we can see the establishment of precision medicine modalities in an attempt improve the quality of life of patients with advanced head and neck SCC (Gong et al., 2017). Different responses of OCC cells to drugs in our study showed heterogeneity of the responsible biomarkers in OCC patients. Accurate screening of specific biomarkers from a huge number of molecules in each patient is highly important to achieve personalized precision medicine in OCC (Zhong et al., 2018).

On the other hand, OCC patients suffer from a lack of flexibility in their therapeutic strategy which leads to inadequate or excessive treatment (Montero and Patel, 2015). Similarly, our results revealed that the drugs had different effects on different OCC cell lines. Clinically, different treatment responses in OCC patients show that even targeted therapy with major advances for treating the patients is beneficial only for a subset of patients not all of them (Naruse et al., 2016). 


\section{Conclusion}

Our study investigated the personalized medicine field for providing targeted therapies that it will definitely play a significant role against this deadly cancer. Considering the afore-mentioned results and the advantages of arsenic trioxide and the optimal efficacy of this affordable drug for cell apoptosis, inhibition of colony formation, and reduction of endoglin and VEGF expression by OCC cells, we suggest future in vivo studies and clinical trials on this drug. Considering the heterogeneity of OCC, we should design ideal therapeutic methods such as targeted therapy and use optimal drugs for patients with genetically complex diseases.

\section{Declarations}

\section{Acknowledgments}

This study was financially supported by the Craniomaxillofacial Research Center, Tehran University of Medical Sciences. Also, it was supported by the Iranian Biological Resource Center, Academic Center for Education, Culture, and Research.

\section{Author contributions}

Study conception and design: Samira derakhshan, Masoumeh Asadi, Meysam Ganjibakhsh, Parvaneh Farzaneh.

Acquisition of data: Masoumeh Asadi, Fatemeh Pirzadeh, Sedigheh Rahrotaban, Sahar Tavakoli Shiraji, Meysam Ganjibakhsh.

Analysis and interpretation of data: Masoumeh Asadi, Meysam Ganjibakhsh, Sahar Tavakoli Shiraji.

Drafting of manuscript: Samira Derakhshan, Masoumeh Asadi, Pouyan Aminshakib, Parvaneh Farzaneh Critical revision: Pouyan Aminshakib, Fatemeh Pirzadeh, Sedigheh Rahrotaban, Parvaneh Farzaneh.

\section{Data availability}

The datasets used and/or analyzed during the current study are available from the corresponding author on reasonable request.

\section{Compliance with ethical standards}

\section{Conflicts of interest}

The authors declare no conflict of interests.

\section{Ethics approval}


The ethical committee of Tehran University approved this study (IR.TUMS.DENTISTRY.REC.1397.146).

\section{Consent to participate}

Written informed consent was obtained from each subject or his or her legal representative before inclusion into the study.

\section{Consent for publication}

Not applicable.

\section{References}

AUSONI, S., BOSCOLO-RIZZO, P., SINGH, B., DA MOSTO, M. C., SPINATO, G., TIRELLI, G., SPINATO, R. \& AZZARELLO, G. 2016. Targeting cellular and molecular drivers of head and neck squamous cell carcinoma: current options and emerging perspectives. Cancer and Metastasis Reviews, 35, 413-426.

AUVRAY, M., TOUGERON, D., AUCLIN, E., MOULIN, V., ARTRU, P., HAUTEFEUILLE, V., HAMMEL, P., LECOMTE, T., LOCHER, C. \& SICKERSEN, G. 2019. Efficacy and Safety of Aflibercept in Combination With Chemotherapy Beyond Second-Line Therapy in Metastatic Colorectal Carcinoma Patients: An AGEO Multicenter Study. Clinical colorectal cancer.

BAYSAN, A., YEL, L., GOLLAPUDI, S., SU, H. \& GUPTA, S. 2007. Arsenic trioxide induces apoptosis via the mitochondrial pathway by upregulating the expression of Bax and Bim in human B cells. International journal of oncology, 30, 313-318.

BONNER, J. A., HARARI, P. M., GIRALT, J., COHEN, R. B., JONES, C. U., SUR, R. K., RABEN, D., BASELGA, J., SPENCER, S. A. \& ZHU, J. 2010. Radiotherapy plus cetuximab for locoregionally advanced head and neck cancer: 5-year survival data from a phase 3 randomised trial, and relation between cetuximab-induced rash and survival. The lancet oncology, 11, 21-28.

CAI, X., YU, Y., HUANG, Y., ZHANG, L., JIA, P., ZHAO, Q., CHEN, Z., TONG, J., DAI, W. \& CHEN, G. 2003. Arsenic trioxide-induced mitotic arrest and apoptosis in acute promyelocytic leukemia cells. Leukemia, 17, 1333-1337.

CHEN, Y. C., LIN-SHIAU, S. Y. \& LIN, J. K. 1998. Involvement of reactive oxygen species and caspase 3 activation in arsenite-induced apoptosis. Journal of cellular physiology, 177, 324-333.

DRUKER, B. J., GUILHOT, F., O'BRIEN, S. G., GATHMANN, I., KANTARJIAN, H., GATTERMANN, N., DEININGER, M. W., SILVER, R. T., GOLDMAN, J. M. \& STONE, R. M. 2006. Five-year follow-up of patients receiving imatinib for chronic myeloid leukemia. New England Journal of Medicine, 355, 2408-2417.

FERLAY, J., SOERJOMATARAM, I., DIKSHIT, R., ESER, S., MATHERS, C., REBELO, M., PARKIN, D. M., FORMAN, D. \& BRAY, F. 2015. Cancer incidence and mortality worldwide: sources, methods and major 
patterns in GLOBOCAN 2012. International journal of cancer, 136, E359-E386.

FISHER, R., PUSZTAI, L. \& SWANTON, C. 2013. Cancer heterogeneity: implications for targeted therapeutics. British journal of cancer, 108, 479-485.

FRANKEN, N. A., RODERMOND, H. M., STAP, J., HAVEMAN, J. \& VAN BREE, C. 2006. Clonogenic assay of cells in vitro. Nature protocols, 1, 2315-2319.

GANJIBAKHSH, M., AMINISHAKIB, P., FARZANEH, P., KARIMI, A., FAZELI, S. A. S., RAJABI, M., NASIMIAN, A., NAINI, F. B., RAHMATI, H. \& GOHARI, N. S. 2017. Establishment and Characterization of Primary Cultures from Iranian Oral Squamous Cell Carcinoma Patients by Enzymatic Method and Explant Culture. Journal of Dentistry (Tehran, Iran), 14, 191.

GANJIBAKHSH, M., MONSHIZADEH, R., NASIMIAN, A., AMINISHAKIB, P., FARZANEH, P., TAVAKOLI SHIRAJI, S., GHARAJEI, A., RAHROTABAN, S., BAGHAEI, F. \& GOHARI, N. S. 2018. Anti-angiogenic efficacy of aflibercept and bevacizumab in primary oral squamous cell carcinoma cells. Journal of Oral Pathology \& Medicine, 47, 575-582.

GIULIANI, J. \& BONETTI, A. 2016. The development of hypertension in metastatic colorectal cancer patients treated with aflibercept: the role of systolic and diastolic blood pressure before starting treatment. Recenti progressi in medicina, 107, 199-200.

GONG, W., XIAO, Y., WEI, Z., YUAN, Y., QIU, M., SUN, C., ZENG, X., LIANG, X., FENG, M. \& CHEN, Q. 2017. Toward the use of precision medicine for the treatment of head and neck squamous cell carcinoma. Oncotarget, 8, 2141.

KUIVENHOVEN, M. \& MASON, K. 2019. Arsenic (Arsine) Toxicity. StatPearls [Internet]. StatPearls Publishing.

KUMAR, P., GAO, Q., NING, Y., WANG, Z., KREBSBACH, P. H. \& POLVERINI, P. J. 2008. Arsenic trioxide enhances the therapeutic efficacy of radiation treatment of oral squamous carcinoma while protecting bone. Molecular cancer therapeutics, 7, 2060-2069.

LIU, M.-H., FU, W.-J., CUI, Y.-H., GUO, Q.-N. \& ZHOU, Y. 2016. Downregulation of Semaphorin-3F is associated with poor prognostic significance in osteosarcoma patients. American journal of cancer research, 6, 2252.

MĂRGĂRITESCU, C., SIMIONESCU, C., MOGOANTĂ, L., BADEA, P., PIRICI, D., STEPAN, A. \& CIUREA, R. 2008. Endoglin and microvessel density in oral squamous cell carcinoma. Rom J Morphol Embryol, 49, 321-6.

MARKOPOULOS, A. 2012. Current aspects on oral squamous cell carcinoma, Open Dent. J, 6, 126-130. 
MAWARDI, H., ENZINGER, P., MCCLEARY, N., MANON, R., VILLA, A., TREISTER, N. \& WOO, S.-B. 2016. Osteonecrosis of the jaw associated with ziv-aflibercept. Journal of gastrointestinal oncology, 7, E81.

MILLER, W. H., SCHIPPER, H. M., LEE, J. S., SINGER, J. \& WAXMAN, S. 2002. Mechanisms of action of arsenic trioxide. Cancer research, 62, 3893-3903.

MONTERO, P. H. \& PATEL, S. G. 2015. Cancer of the oral cavity. Surgical Oncology Clinics, 24, $491-508$.

NAKAOKA, T., OTA, A., ONO, T., KARNAN, S., KONISHI, H., FURUHASHI, A., OHMURA, Y., YAMADA, Y., HOSOKAWA, Y. \& KAZAOKA, Y. 2014. Combined arsenic trioxide-cisplatin treatment enhances apoptosis in oral squamous cell carcinoma cells. Cellular Oncology, 37, 119-129.

NARUSE, T., YANAMOTO, S., MATSUSHITA, Y., SAKAMOTO, Y., MORISHITA, K., OHBA, S., SHIRAISHI, T., YAMADA, S. I., ASAHINA, I. \& UMEDA, M. 2016. Cetuximab for the treatment of locally advanced and recurrent/metastatic oral cancer: an investigation of distant metastasis. Molecular and clinical oncology, 5, 246-252.

NASR, R. 2010. Eradication of acute promyelocytic leukemia-initiating cells by PML/RARA-targeting. International journal of hematology, 91, 742-747.

NETWORK, C. G. A. 2015. Comprehensive genomic characterization of head and neck squamous cell carcinomas. Nature, 517, 576-582.

PARK, W. H., CHO, Y. H., JUNG, C. W., PARK, J. O., KIM, K., IM, Y. H., LEE, M. H., KANG, W. K. \& PARK, K. 2003. Arsenic trioxide inhibits the growth of A498 renal cell carcinoma cells via cell cycle arrest or apoptosis. Biochemical and biophysical research communications, 300, 230-235.

PULTE, D. \& BRENNER, H. 2010. Changes in survival in head and neck cancers in the late 20th and early 21 st century: a period analysis. The oncologist, 15, 994.

RILEY, R. D., ENSOR, J., SNELL, K. I., DEBRAY, T. P., ALTMAN, D. G., MOONS, K. G. \& COLLINS, G. S. 2016. External validation of clinical prediction models using big datasets from e-health records or IPD metaanalysis: opportunities and challenges. bmj, 353, i3140.

RODRÍGUEZ-REMÍREZ, M., DEL PUERTO-NEVADO, L., ACEÑERO, M. J. F., EBRAHIMI-NIK, H., CRUZ-RAMOS, M., GARCÍA-GARCÍA, L., SOLANES, S., BAÑOS, N., MOLINA-ROLDÁN, E. \& GARCÍA-FONCILLAS, J. 2020. Strong Antitumor Activity of Bevacizumab and Aflibercept in Neuroendocrine Carcinomas: In-Depth Preclinical Study. Neuroendocrinology, 110, 50-62.

SHEIKHOLESLAMI, K., ALI SHER, A., LOCKMAN, S., KROFT, D., GANJIBAKHSH, M., NEJATI-KOSHKI, K., SHOJAEI, S., GHAVAMI, S. \& RASTEGAR, M. 2019. Simvastatin induces apoptosis in medulloblastoma brain tumor cells via mevalonate cascade prenylation substrates. Cancers, 11, 994. 
TANDON, P., DADHICH, A., SALUJA, H., BAWANE, S. \& SACHDEVA, S. 2017. The prevalence of squamous cell carcinoma in different sites of oral cavity at our Rural Health Care Centre in Loni, Maharashtra-a retrospective 10-year study. Contemporary Oncology, 21, 178.

TELEANU, R. I., CHIRCOV, C., GRUMEZESCU, A. M. \& TELEANU, D. M. 2020. Tumor Angiogenesis and AntiAngiogenic Strategies for Cancer Treatment. Journal of Clinical Medicine, 9, 84.

VAN CUTSEM, E., KOHNE, C.-H., LÁNG, I., FOLPRECHT, G., NOWACKI, M. P., CASCINU, S., SHCHEPOTIN, I., MAUREL, J., CUNNINGHAM, D. \& TEJPAR, S. 2011. Cetuximab plus irinotecan, fluorouracil, and leucovorin as first-line treatment for metastatic colorectal cancer: updated analysis of overall survival according to tumor KRAS and BRAF mutation status. J Clin Oncol, 29, 2011-2019.

ZANDBERG, D. P., TALLON, L. J., NAGARAJ, S., SADZEWICZ, L. K., ZHANG, Y., STROME, M. B., ZHAO, X. E., VAVIKOLANU, K., ZHANG, X. \& PAPADIMITRIOU, J. C. 2019. Intratumor genetic heterogeneity in squamous cell carcinoma of the oral cavity. Head \& neck, 41, 2514-2524.

ZHENG, D., YE, T., HU, H., ZHANG, Y., SUN, Y., XIANG, J. \& CHEN, H. 2018. Upfront surgery as first-line therapy in selected patients with stage IIIA non-small cell lung cancer. The Journal of thoracic and cardiovascular surgery, 155, 1814-1822. e4.

ZHONG, L., LIU, Y., WANG, K., HE, Z., GONG, Z., ZHAO, Z., YANG, Y., GAO, X., LI, F. \& WU, H. 2018. Biomarkers: paving stones on the road towards the personalized precision medicine for oral squamous cell carcinoma. BMC cancer, 18, 911.

\section{Figures}


A

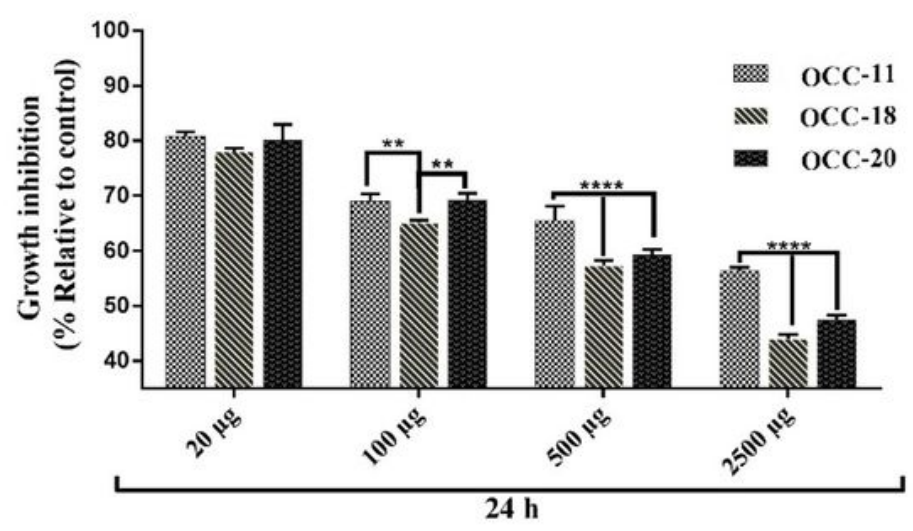

C

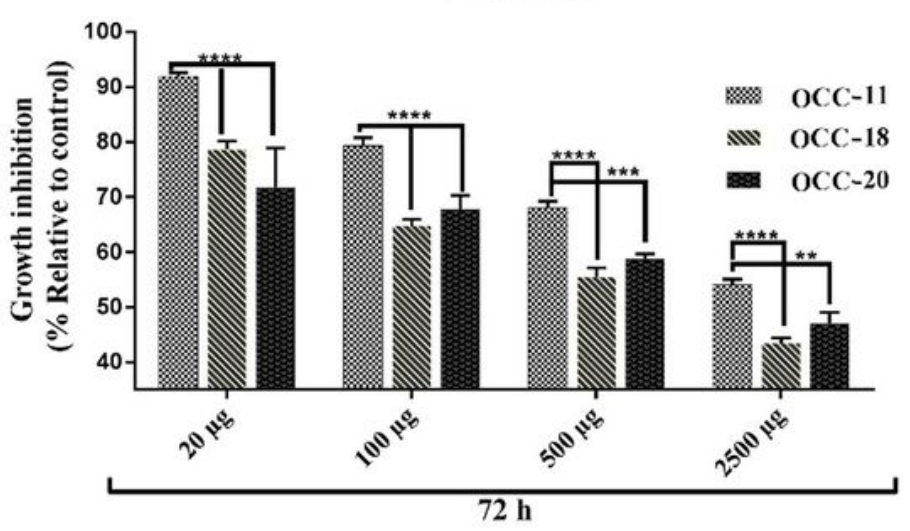

$\mathbf{E}$

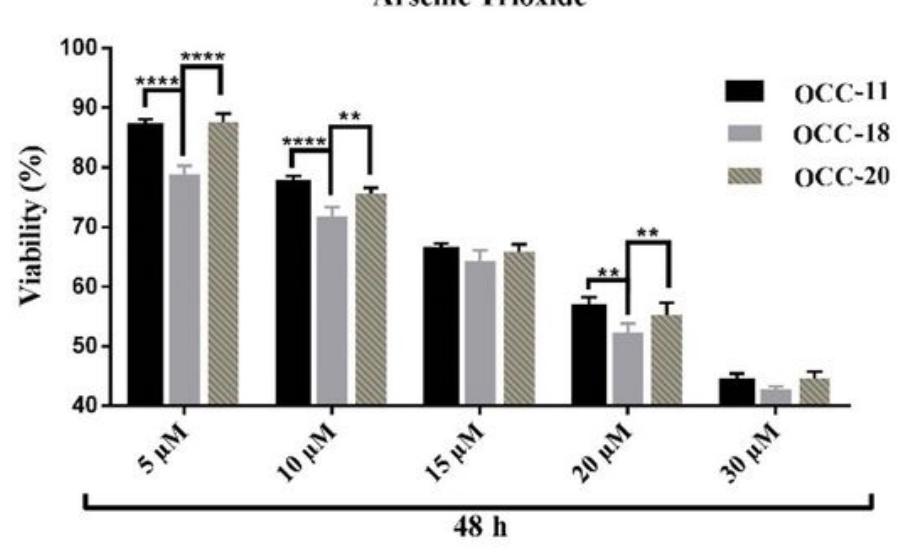

B

Aflibercept

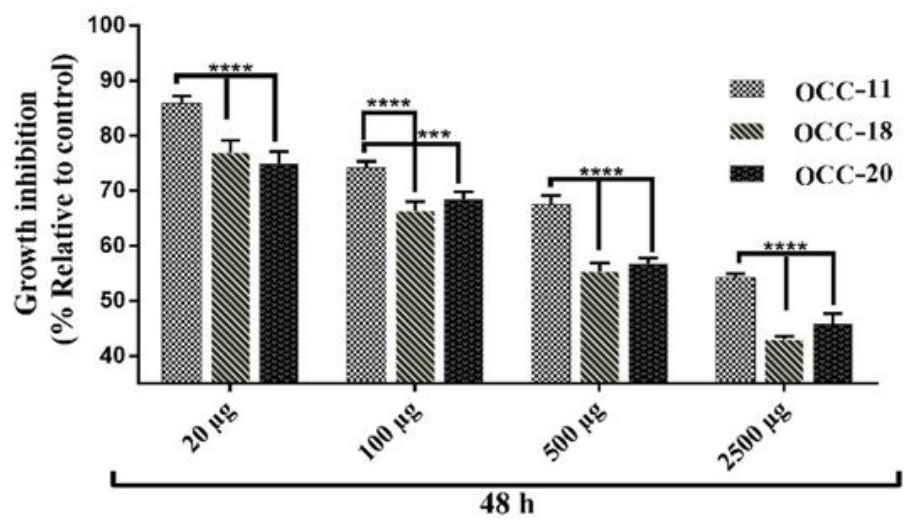

D

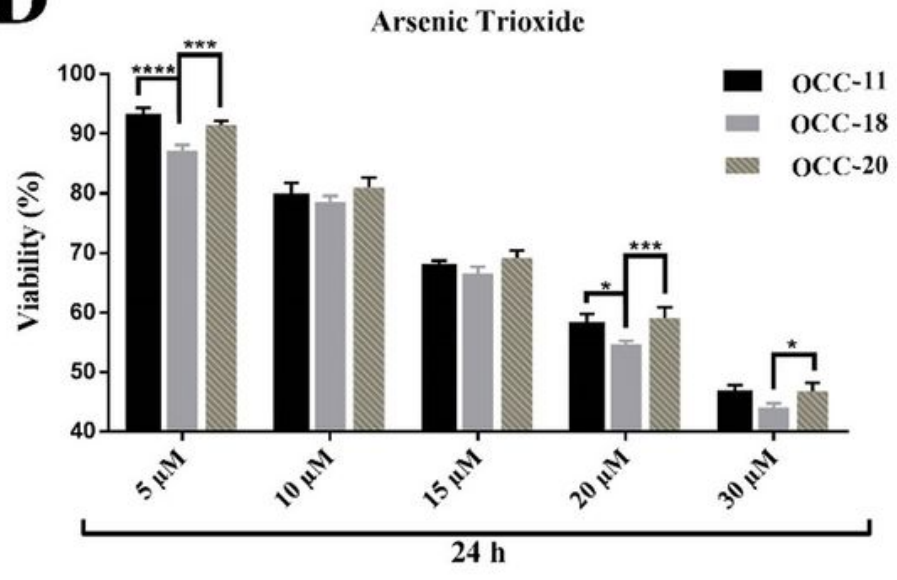

$\mathbf{F}$

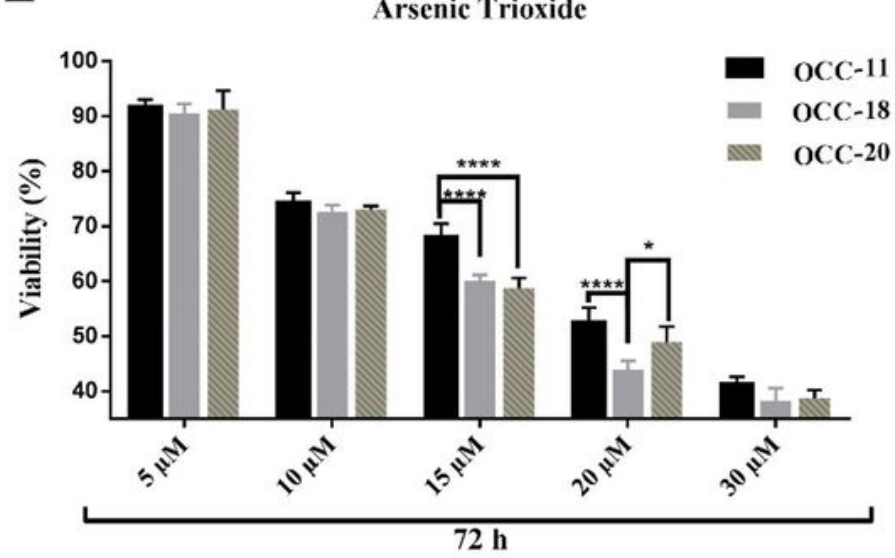

\section{Figure 1}

Aflibercept induced growth inhabitation and arsenic trioxide reduced cell viability in three OCC cell lines. Cell proliferation assay of OCC-11, OCC-18, and OCC-20 cell lines treated with 20-2500 $\mu \mathrm{g}$ aflibercept, using dose depended on analysis by MTT, was done at $24 \mathrm{~h}(\mathrm{~A}), 48 \mathrm{~h}(\mathrm{~B})$, and $72 \mathrm{~h}(\mathrm{C})$. Viability assays of the three OCC cell lines were performed using dose-dependent analysis by MTT, performed at $24 \mathrm{~h}$ (D), 48 
$h(E)$, and $72 h(F)$. OCC cells were treated with $5-30 \mu \mathrm{M}$ arsenic trioxide. Data are expressed as mean \pm standard error of the mean.

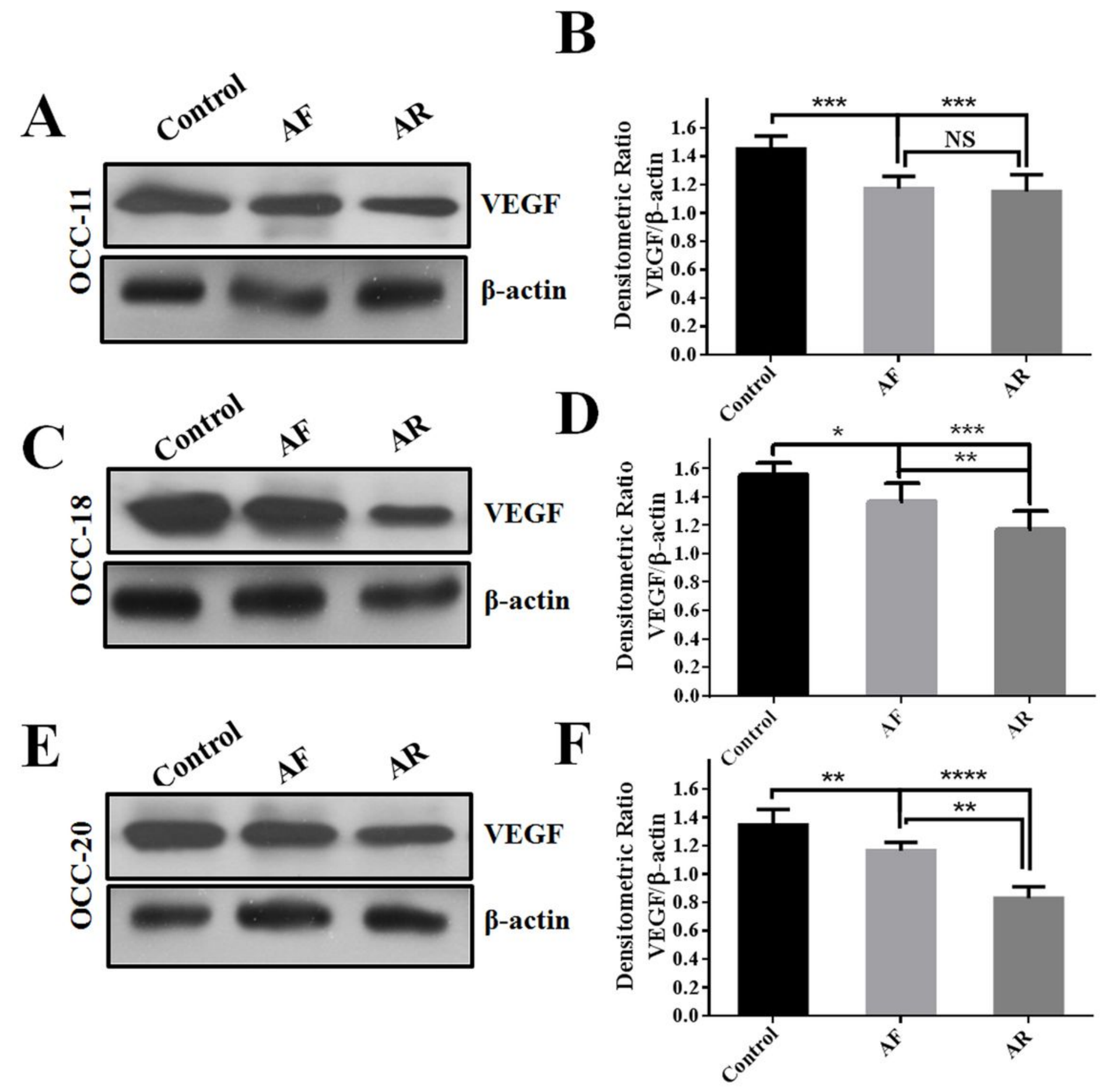

Figure 2

Western blot assay to evaluate VEGF protein expression. Aflibercept (AF) and arsenic trioxide (AR) decreased VEGF expression by OCC cells at $48 \mathrm{~h}$. (A-B) VEGF expression by OCC-11 cells treated with aflibercept and arsenic trioxide. (C-D) VEGF expression by OCC-18 cells treated with aflibercept and arsenic trioxide. (E-F) VEGF expression by OCC-20 cells treated with aflibercept and arsenic trioxide. 
There was a decreasing percentage of VEGF expression in all tested cell lines compared with the control group. Data are expressed as mean \pm standard error of the mean.

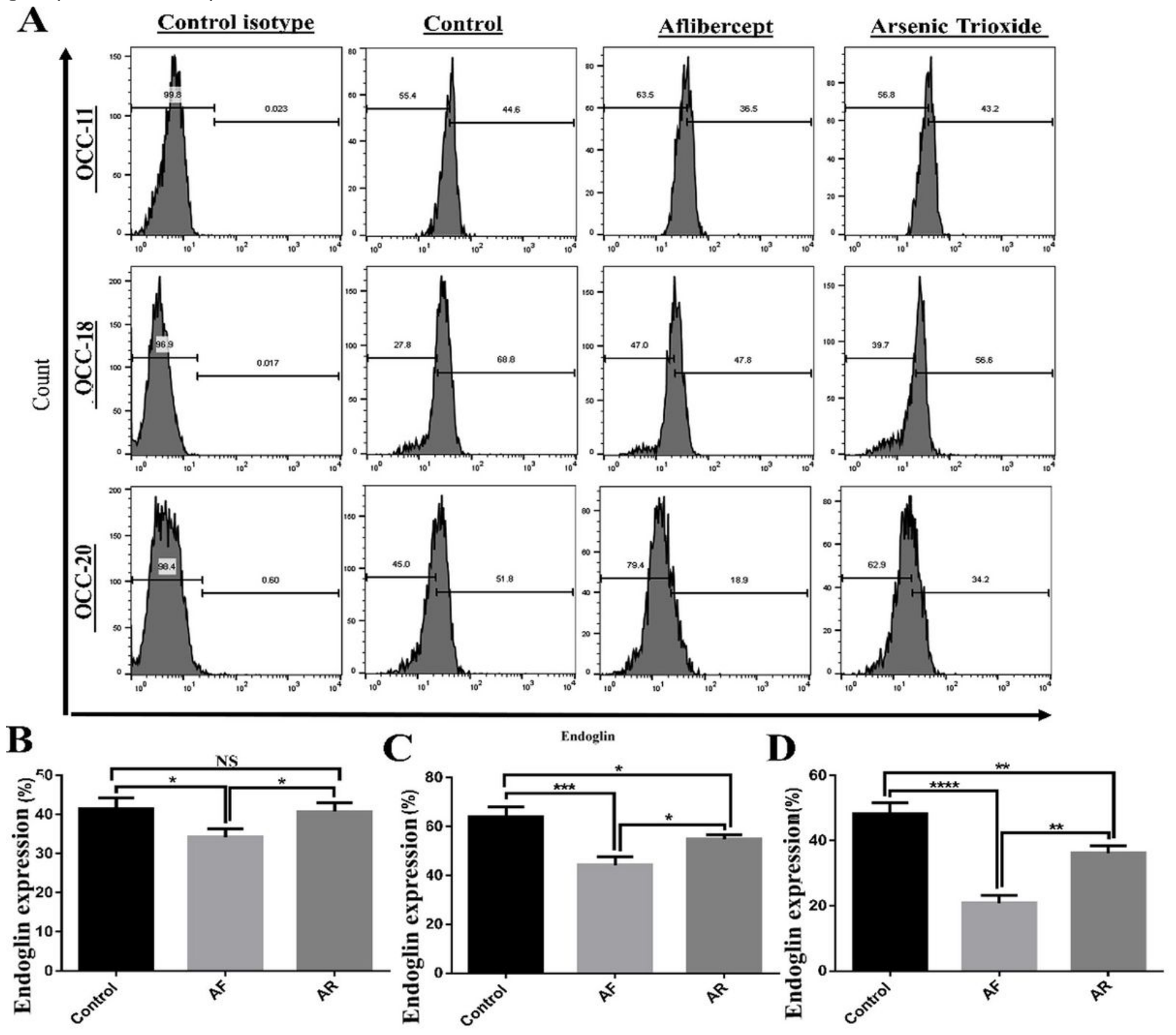

Figure 3

Aflibercept and arsenic trioxide decreased Endoglin protein expression in OCC treated cells. (A) For flow cytometry, control cells (untreated), aflibercept $(100 \mu \mathrm{g})$, and arsenic trioxide treated cells $(10 \mu \mathrm{M})$ were collected at $48 \mathrm{~h}$ and underwent flow cytometry assay using the standard protocol. The results were analyzed by FlowJo software V-10. (B-D) Quantification of results in part A, flow cytometry (B) Endoglin expression by OCC-11 cells treated with aflibercept (AF), and arsenic trioxide (AR). (C) Endoglin expression by OCC-18 cells treated with aflibercept and arsenic trioxide. (D) Endoglin expression by OCC20 cells treated with aflibercept and arsenic trioxide. Data are expressed as mean \pm standard error of the mean. 


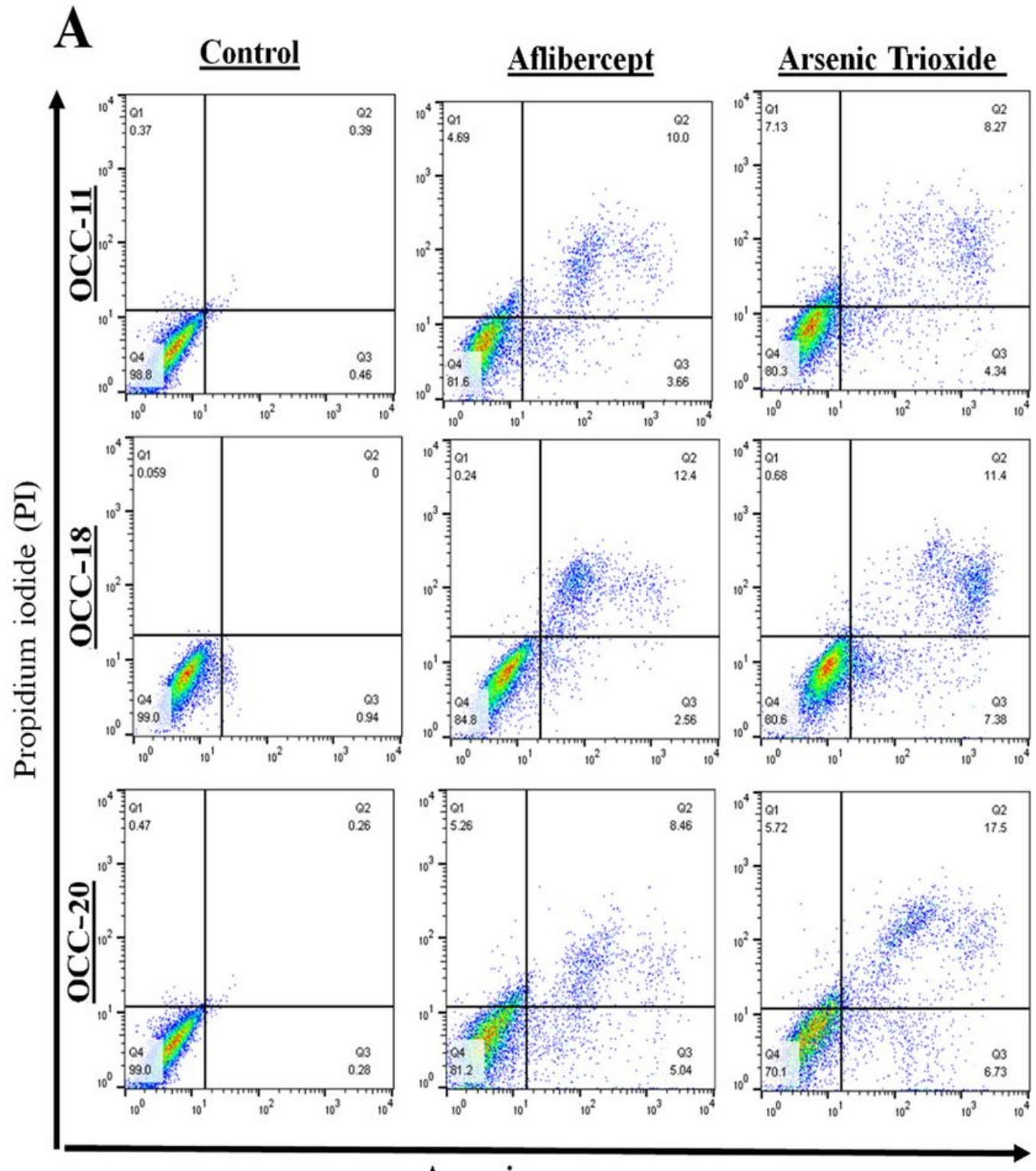

B
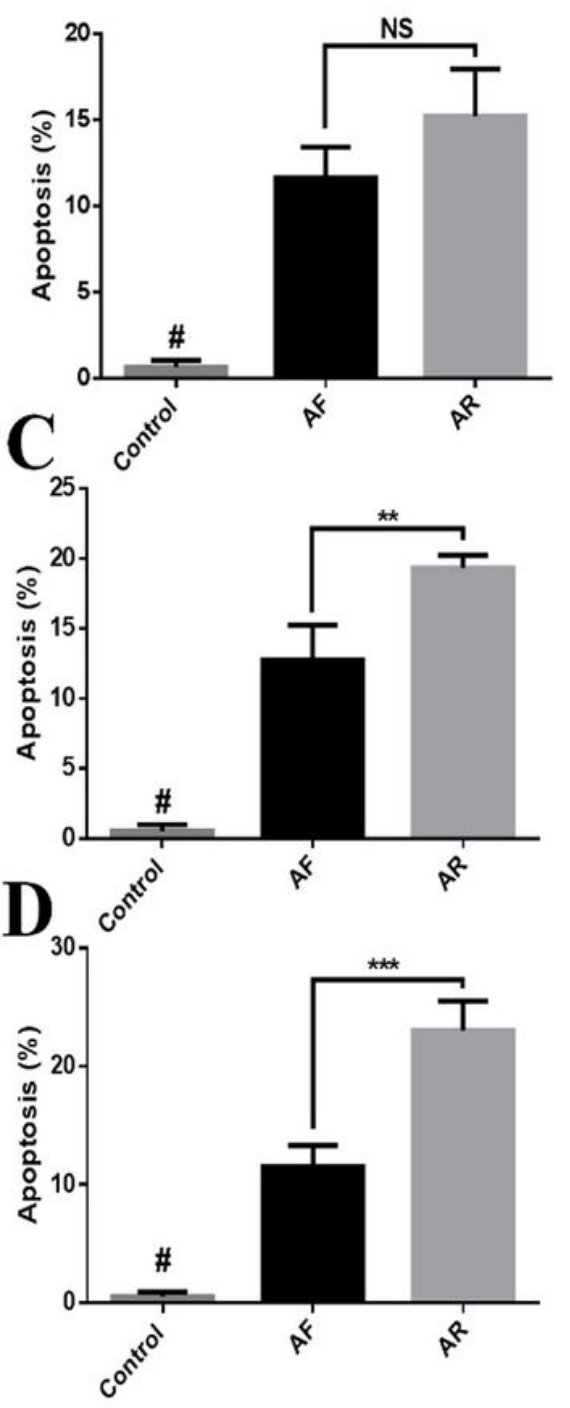

Annexin

Figure 4

Effect of aflibercept and arsenic trioxide on apoptosis of treated OCC cells. (A) For flow cytometry, control cells (untreated), aflibercept $(100 \mu \mathrm{g})$, and arsenic trioxide treated cells $(10 \mu \mathrm{M})$ were collected at $48 \mathrm{~h}$ and underwent flow cytometry using the standard protocol. Apoptotic cells were detected using annexin and propidium iodide (PI) and were then analyzed by FlowJo software V-10. (B-D) Quantification of results in part A, flow cytometry (B) Percentage of apoptotic OCC-11 cells treated with aflibercept and arsenic trioxide. (C) Percentage of apoptotic OCC-18 cells treated with aflibercept and arsenic trioxide. (D) Percentage of apoptotic OCC-20 cells treated with aflibercept and arsenic trioxide. Data are expressed as mean \pm standard error of the mean. 
A
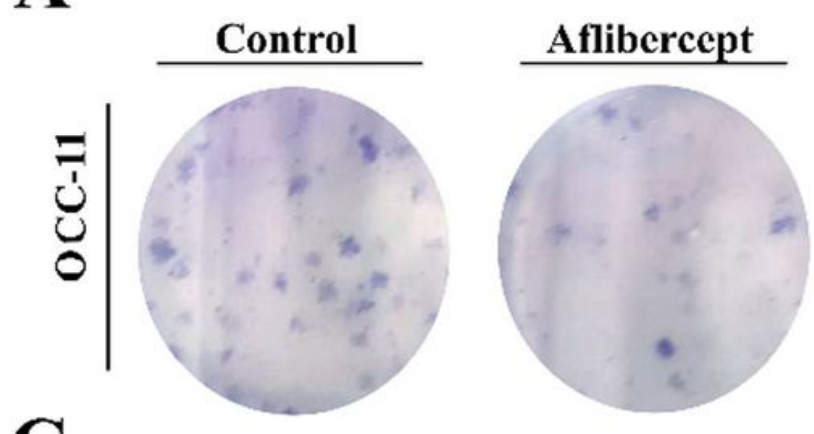

C
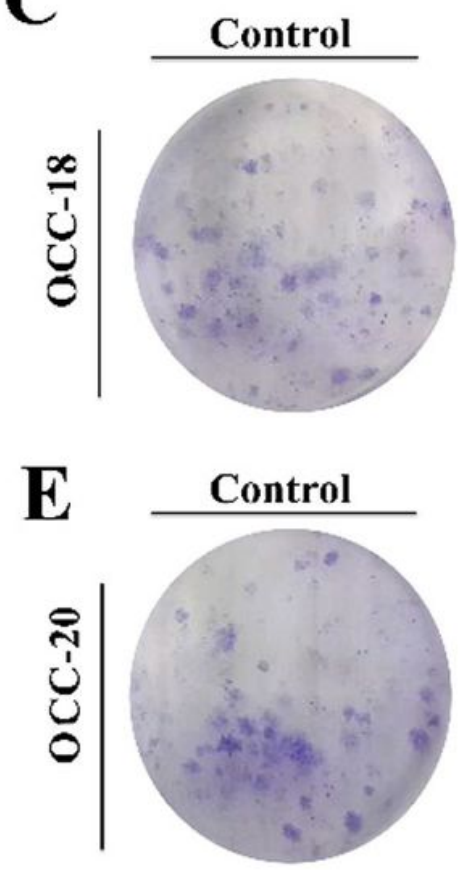
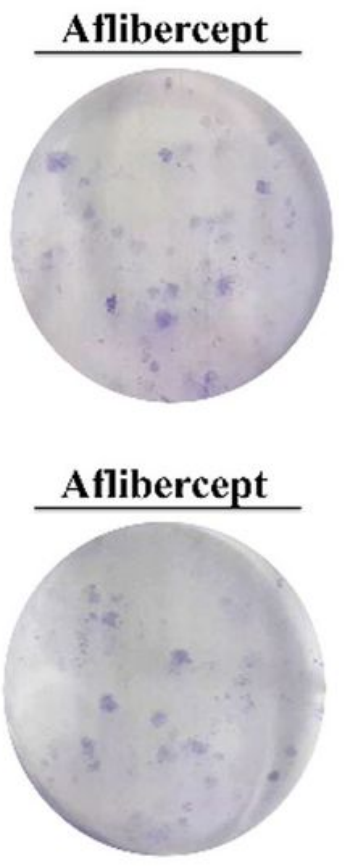

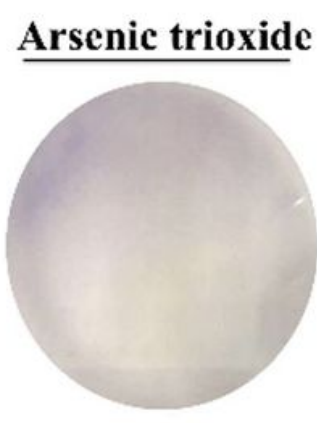

$\underline{\text { Arsenic trioxide }}$
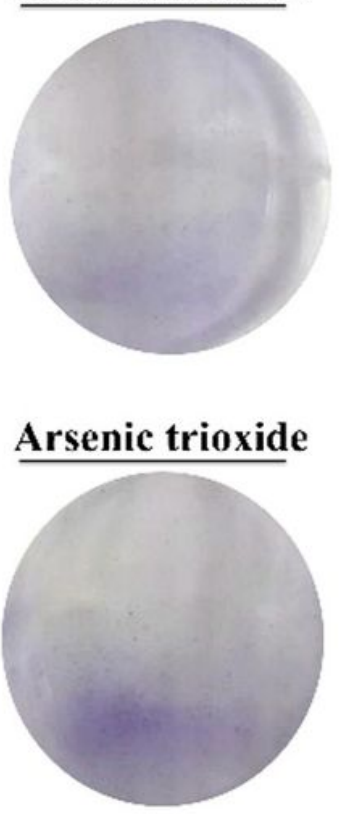

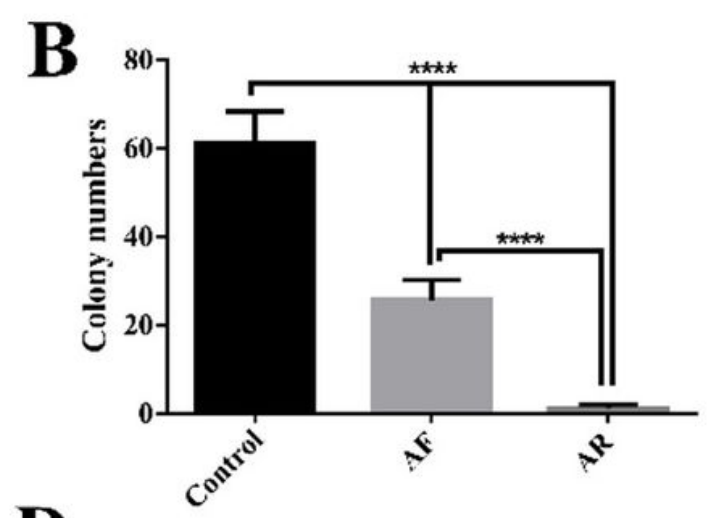

D
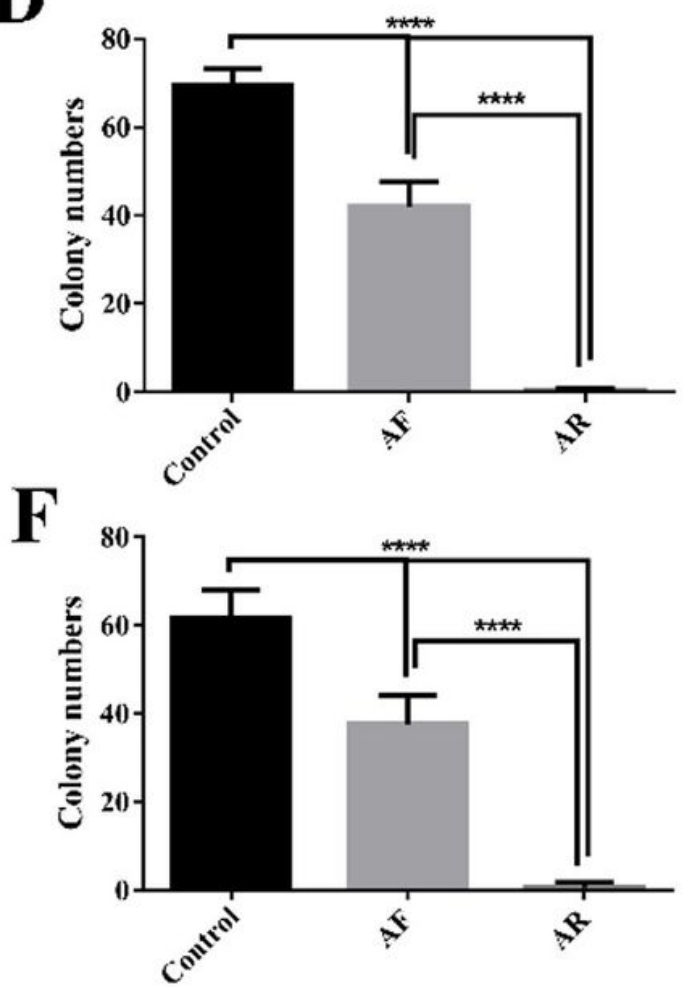

Figure 5

Treatment with aflibercept and arsenic trioxide decreased colony formation in three OCC cell lines. For the colony formation assay, OCC-11(A), OCC-18(C), and OCC-20 (E) were treated with $100 \mu \mathrm{g}$ aflibercept and $10 \mu \mathrm{M}$ arsenic trioxide. Fourteen days later, the cells were fixed and stained using the standard protocol and then photographs were quantified by ImageJ and analyzed by GraphPad. (B, D, F) Quantification of results in part $A, C, E ;(B)$ Colony number of OCC-11 cells treated with aflibercept (AF) and arsenic trioxide (AR). (C) Colony number of OCC-18 cells treated with aflibercept and arsenic trioxide. (D) Colony number of OCC-20 cells treated with aflibercept and arsenic trioxide. Data are expressed as mean \pm standard error of the mean. 


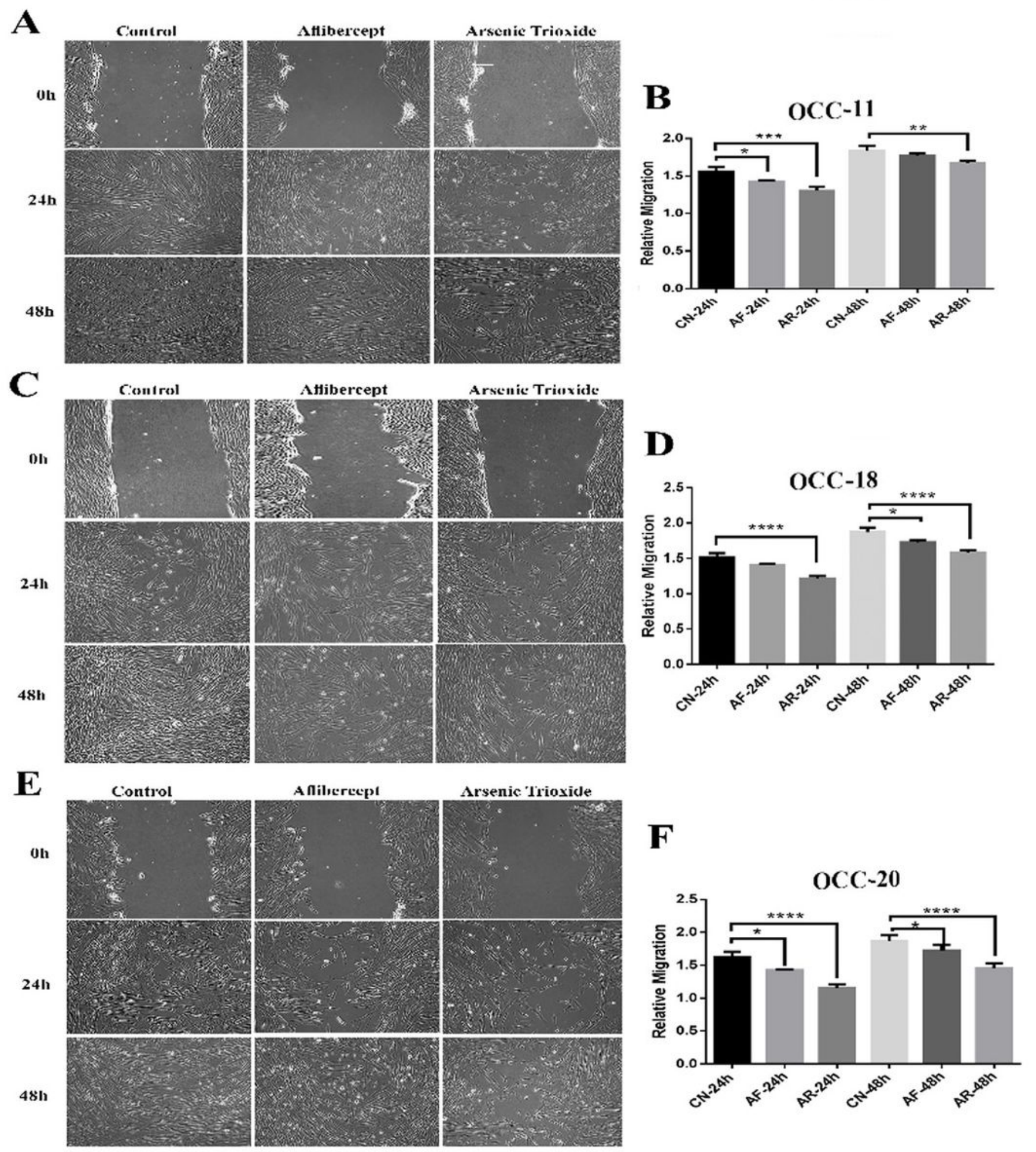

\section{Figure 6}

For cell migration assay, first, OCC-11 (A), OCC-18 (C), and OCC-20 (E) cell lines were treated with $100 \mu \mathrm{g}$ aflibercept and $10 \mu \mathrm{M}$ arsenic trioxide. Then, photographs were taken at 0,24 , and $48 \mathrm{~h}$. Finally, photographs were quantified using ImageJ software and analyzed by GraphPad. (B, D, F) Quantification of images in part A, C, E (B) Relative migration in OCC-11 cells treated with aflibercept (AF) and arsenic trioxide (AR). (C) Relative migration in OCC-18 cells treated with aflibercept and arsenic trioxide. (D) 
Relative migration in OCC-20 cells treated with aflibercept and arsenic trioxide. Data are expressed as mean \pm standard error of the mean.

\section{Supplementary Files}

This is a list of supplementary files associated with this preprint. Click to download.

- Asadi.pdf

- FatemehPirzadeh2.pdf

- Meysamganjibakhsh.pdf

- OCC111.pdf

- OCC112.pdf

- occ181.pdf

- occ182.pdf

- OCC201.pdf

- tablesupplementary.docx

- occ202.pdf

- OSCC11.pdf

- oscc18.pdf

- oscc20.pdf

- ParvanehFarzaneh.pdf

- SaharTavakoliShiraji.pdf

- SedighehRahrotaban.pdf

- aminshakib.pdf

- derakhshan.pdf

- supplementaryfig1.jpg

- supplementaryfig2.jpg 